\title{
Financing Shortfalls and the Value of Aggregate Liquidity*
}

\author{
Andrea L. Eisfeldt ${ }^{\dagger}$ \\ Adriano A. Rampini ${ }^{\ddagger}$ \\ Northwestern University \\ Duke University
}

March 2009

\begin{abstract}
This paper studies the level and dynamics of the value of aggregate liquidity induced by firms' financing shortfalls. We model liquidity and cash flows as internal funds available for investment in an economy where external funds are costly. We study whether the use of liquidity to hedge investment opportunities can generate substantial liquidity premia with empirically observed countercyclical properties, and show how firms' financial positions affect the value of aggregate liquidity. Cash flows affect the "natural supply" of liquidity and are procyclical. Thus, we argue that shortfalls between firms' financing needs and available liquid funds are more likely to occur in bad times when current cash flows are low, rendering liquidity premia countercyclical. We investigate the relationship between such shortfalls and the value of aggregate
\end{abstract}

*We thank Janice Eberly, Gerald Garvey, Lars Peter Hansen, Arvind Krishnamurthy, Robert McDonald, Raoul Minetti, Vinay Nair, Stavros Panageas, Dimitris Papanikolaou, Sergio Rebelo, Neng Wang, and seminar participants at UCLA, Northwestern, the SED annual meeting, the WFA annual meeting, the UBC summer conference, University of Vienna, University of Indiana, Berkeley, University of Florida, Vanderbilt, University of North Carolina, the Beyond Liquidity: Modeling Frictions in Finance and Macroeconomics Conference, the SITE workshop on Dynamic Investment and Financing, and the University of Oslo for helpful comments.

${ }^{\dagger}$ Department of Finance, Kellogg School of Management, Northwestern University, 2001 Sheridan Road, Evanston, IL, 60208. Phone: (847) 491-7843. Email: a-eisfeldt@northwestern.edu.

${ }^{\ddagger}$ Duke University, Fuqua School of Business, 1 Towerview Drive, Durham, NC, 27705. Phone: (919) 660-7797. Email: rampini@duke.edu. 
liquidity empirically using US Flow of Funds and Compustat data. JEL Classification: G30; G12; G32; D92; E22; E44. 


\section{Introduction}

Liquid assets yield low returns, and tend to have higher prices and therefore lower expected returns when aggregate conditions are poor. We construct a model of the level and dynamics of the value of aggregate liquidity induced by firms' financing shortfalls. Liquid assets are defined to be those which can be quickly reallocated at a low cost. In our model, liquidity and cash flows constitute internal funds available for investment in an economy where external funds are costly. The liquidity premium is then measured as the premium on funds which can be costlessly used for immediate investment. The use of liquidity to hedge investment opportunities can generate sizeable liquidity premia with the empirically observed cyclical properties. The model generates liquidity accumulation even if the expected return on liquid assets is much lower than that on real capital, and delivers a liquidity premium which is substantially countercyclical.

A lack of coincidence between sources and uses of funds is needed to generate corporate demand for liquid assets. The occurrence of such a lack of coincidence is not a foregone conclusion; in standard models the main use of funds (investment) is highly correlated with the main source of funds (cash flows). We construct a model where we break this strong correlation by introducing corporate finance frictions between the corporate and consumer sectors. Firms use funds to make discretionary and non-discretionary payments to investors, and to invest in productive investment opportunities. Likewise, firms have two sources of funds, internal funds, and new funds from consumers. Internal funds are the sum of current cash flow less committed payouts and the firm's stock of liquid savings. Since raising external finance is costly, the value of liquidity is high when investment opportunities and available internal funds do not coincide. When such a mismatch occurs, the value of liquid assets inside the corporate sector where investment opportunities arise exceeds their intrinsic value. Liquid assets bear a convenience yield because they are fungible and this convenience yield varies with firms' financing shortfalls. We study the resulting process for the value of liquid assets, and their expected return, and relate this value to measures of firms' financing shortfalls. 
Much of the existing theoretical literature studying the demand for liquid assets has focused on consumers/investors. ${ }^{1}$ However, it turns out to be difficult for models of consumers to generate a sizable liquidity premium. Consumers use buffer stocks of liquid assets to avoid selling illiquid assets, or costly borrowing. Moreover, in calibrated models consumers much prefer insuring negative shocks by saving out of them, and can effectively avoid selling even slightly illiquid assets. ${ }^{2}$ Firms may be a more important and quantitatively relevant source of liquidity demand for three reasons: First, firms are subject to larger shocks than consumers. Second, firms may try to limit internal funds because of agency problems, as in Jensen (1986) and Stulz (1990). Finally, and relatedly, firms rely more heavily on "external finance" than do consumers.

We build on models such as Holmström and Tirole (1996, 1998, 2001), which have developed important microeconomic foundations for corporate liquidity policies. $^{3}$ Our model uses lessons from corporate finance to extend the canonical consumption based asset pricing model, or business cycle model to include a role for corporate liquidity demand. ${ }^{4}$

To motivate our model, it is useful to consider the role of liquidity inside firms from the standpoint of standard asset pricing and macroeconomic models. Consider first the canonical consumption based asset pricing model with CRRA utility and a coefficient of relative risk aversion greater than one. In such models investment opportunities arrive as positive shocks to expected returns and are good news. ${ }^{5}$ When

\footnotetext{
${ }^{1}$ See, for example, Diamond and Dybvig (1983), Aiyagari and Gertler (1991), Heaton and Lucas (1996), Vayanos (1998), Vayanos and Vila (1999), Huang (2003), Allen and Gale (2004), Eisfeldt (2004), Gârleanu, and Pedersen (2004), Kiyotaki and Moore (2004), Vayanos (2004), Duffie, Gârleanu, and Pedersen (2005).

${ }^{2}$ See, Eisfeldt (2007) for a calibrated model of portfolio choice amongst riskless securities with varying liquidity. Constantinides (1986), Aiyagari and Gertler (1991), Heaton and Lucas (1996) study the equity premium in economies with transactions costs.

${ }^{3}$ See also Kiyotaki and Moore (1997), Myers and Rajan (1998), Gorton and Huang (2004), Rochet and Villeneuve (2004), and Tirole (2006).

${ }^{4}$ See also the recent empirical asset pricing research into corporate liquidity and stock returns in Greenwood (2005) and Livdan, Sapriza, and Zhang (2005).

${ }^{5}$ See Campbell (1996).
} 
they arrive, investors are "richer" and can consume and/or invest more. With risk aversion greater than one, the income effect dominates the substitution effect and investors invest a lower fraction of income, and consume a higher fraction. Thus, investors actually want to consume relatively more instead of investing relatively more upon the arrival of investment opportunities, and there is never a mismatch between investment opportunities and available funds. Moreover, this model implies that investors should hedge states without investment opportunities. This runs counter to theories of hedging in corporate finance where firms instead desire to hedge states where investment opportunities arrive. ${ }^{6}$ The difference between the two frameworks is that the corporate finance literature has focused more on the frictions between the agents who have funds, and the agents who have investment opportunities. Investment opportunities are no longer just "good news" if it is costly to take advantage of them. In other words, the fact that it may be costly to move funds to where investment opportunities reside alleviates the income effect of the arrival of such opportunities. This allows the substitution effect to dominate, leading consumers to invest a larger fraction of income rather than consuming it.

Next, consider the decentralized version of the standard real business cycle model. The decentralization works through complete markets, and hence there are no binding frictions between consumers and firms; Modigliani and Miller (1958) irrelevance holds in these economies. Thus, whether funds reside in the corporate or consumer sector is irrelevant. Moreover, due to consumption smoothing motives, consumers want to invest more in total (albeit a smaller fraction of income) when productivity is high. Since this is when current output is also high, the level of investment is high when funds for investment are plentiful. Thus, there is no role for corporate liquidity in the standard consumption based asset pricing model, or real business cycle model. ${ }^{7}$

The basic intuition of the model works off of a tradeoff between two frictions which we introduce into the standard consumption based asset pricing model, or

\footnotetext{
${ }^{6}$ See Froot, Scharfstein, and Stein (1994).

${ }^{7}$ See Danthine and Donaldson (2001) for a discussion of market imperfections in real business cycles, and Bernanke, Gertler, and Gilchrist $(1996,1999)$ for models where borrowing constraints provide amplification and persistence to the effects productivity shocks.
} 
business cycle model. Frictions which make raising external finance costly lead firms to accumulate liquidity. We summarize such costs with the label "Myers" costs. ${ }^{8}$ However, firms with too much liquidity are subject to free cash flow agency problems, and this leads firms to pay funds out to consumers. We summarize these costs with the label "Jensen" costs. ${ }^{9}$ These two frictions de-link the value of liquid assets inside and outside the corporate sector, and distinguish the corporate from the consumer sector. ${ }^{10}$

Our tradeoff between costly internal and external finance is very closely related to the tradeoff between under and over investment in Stulz (1990). His model illustrates how committed payouts can reduce the over investment problem, but lead to under investment. Riddick and Whited (2006) study the related question of the corporate propensity to save in the cross section. They study a tradeoff between costly external finance and tax costs of saving, and conduct a structural estimation of the parameters in the model using panel data. The tradeoff in their model is also closely related to ours, but the focus on comparative statics of corporate savings in the cross section over the variance of income shocks and costs of external finance is quite different. Both the theoretical and empirical results in their paper are complementary to ours.

The second modification we introduce is designed to de-link available funds and investment opportunities. We model investment opportunities as shocks to the price of new capital. ${ }^{11}$ If investment opportunities instead come from persistence in output productivity, then cash flows and investment opportunities are likely to coincide. Modeling investment opportunities in the form of lower new capital prices not only

\footnotetext{
${ }^{8}$ See Myers and Majluf (1984).

${ }^{9}$ See Jensen $(1986,1993)$ and Stulz (1990).

${ }^{10}$ See Dow, Gorton, and Krishnamurthy (2005) for a model of interest rates which also builds on a separation between consumers and firms. In their model, external finance is costless but internal funds incur agency costs.

${ }^{11}$ See Kiyotaki and Moore (2005) and Albuquerque and Wang (2005) for other model economies in which investment opportunities are modeled this way. Fisher (2006), and Primiceri, Justiniano, and Tambalotti (2008) document the importance of such technological specific change shocks for explaining business cycle quantity dynamics. Papanikolaou (2008) shows that investment specific technological change is a source of systematic risk, and documents that such shocks induce reallocation from consumption expenditures towards investment expenditures.
} 
prevents the coincidence of available funds and investment opportunities, but also provides a counterbalance to the income effect discussed above by making the substitution effect towards higher investment stronger.

We analyze our model and study the level and variation in the value of liquidity as a function of the aggregate state. The model also provides implications for corporate payout policy, external finance activity, and corporate liquidity policy. ${ }^{12}$ We find that the value of aggregate liquidity is highest when investment opportunities arise and current productivity, and hence internal cash flow, or the "natural supply" of liquidity, is low. In these states, firms draw down their balances of liquid assets and raise external finance. Firms accumulate liquidity only when current output is high and there is no investment opportunity, and otherwise draw down their liquid funds.

Using the US Flow of Funds and Compustat data, we examine the time series properties of firms' financing shortfalls. We construct time series of the shortfalls between aggregate internal funds and aggregate investment, and also compare our aggregate measure to a firm level measure that does not net out firm level shortfalls and surpluses. We compare the relationship between financing shortfalls and the value of aggregate liquidity in data generated from the model economy and US data. We expect the value of aggregate liquidity to be high when there is a shortfall in the aggregate corporate sector and find a positive relationship between our measure of shortfalls and the spread between commercial paper and treasury bills, a commonly used liquidity measure. Our measure of financing shortfalls also has predictive power for this spread.

Section 2 describes our model and analytical and numerical results, section 3 describes our empirical findings, and section 4 concludes.

\section{Model}

The economy consists of a representative agent who consumes and invests in a representative firm. The economy has two sectors, a consumer sector and a corporate sector. Figure 4 describes the circulation of funds between the consumer and corpo-

\footnotetext{
${ }^{12}$ See also Hennessy and Whited (2005) for a dynamic model of firm finance.
} 
rate sector in a Modigliani Miller economy. In such an economy without frictions, funds circulate costlessly between the consumer and corporate sector and hence it is irrelevant where cash flows arrive, and there is no role for a liquid asset.

Since there is no role for corporate liquidity in such an economy, we introduce two frictions to separate the consumer and corporate sectors. First, because of asymmetric information, monitoring costs, and transactions costs, it is costly to get funds from the consumer to the corporate sector. To capture these costs, we introduce a "Myers operator," $\mathcal{M}(\cdot)$, which takes as an input external finance provided by consumers to firms and returns a cost which is increasing and convex in such funds. We choose a convex cost function for external finance so that we avoid corner solutions (as with linear costs) and non-convexities (as with concave costs), however, it is intuitively reasonable that costs of external finance might be convex in practice. For example, asymmetric information problems and monitoring costs might become increasingly severe as firms seek to sell off a larger fraction of future cash flows. Moreover, since our model is aggregate, one can motivate convexity by the idea that the economy allocates funds to the least information sensitive firms first (or from the consumers with the most superior information), but that as more external funds are needed more information sensitive firms receive funds (or funds arrive from consumers with inferior information). Second, because managers become tempted to use excess internal funds inefficiently, it is costly for the firm to retain operating cash flows. Committed payouts to consumers reduce such agency problems by disciplining managers and offering monitoring. To capture these costs, we introduce a "Jensen operator," $\mathcal{J}(\cdot)$, which takes as an input current free cash flow (current output less committed payouts) and returns a cost which is increasing and convex in such funds. Again, it is reasonable that free cash flow problems might become increasingly severe as companies become more flush with cash since bigger inefficient projects become viable and it is unlikely that there are effective monitoring procedures for such large cash flows in place. Moreover, the Jensen operator takes aggregate free cash flows as an input so the convexity can be motivated by the idea that the economy takes committed payouts from firms with the largest free cash flow problems first (or allocates committed payouts to investors with the lowest monitoring skills), but that 
as free cash flow increases even these firms (or monitors) are left with discretionary funds. Figure 2 describes the circulation of funds between the consumer and corporate sector in the economy with frictions. The two frictions combined create a role for corporate accumulation of liquid assets in addition to investment in productive capital.

Using these cost functions allows us to focus on the aggregate dynamic implications of microeconomic frictions such as information and agency problems, and allows us to more readily match the model to data. The tradeoff is that we may be missing endogenous variation in such costs. ${ }^{13}$ We feel that this specification allows us to take a valuable first step in examining the aggregate effect of these frictions in a tractable dynamic setting which can be used to guide empirical work.

We also add liquidity accumulation to the model. Liquid assets are a risk free store of value, so they can be used for intertemporal insurance. Liquid assets are also fungible; they can be used in the consumer sector for consumption or the corporate sector for investment without incurring any costs. These features lead to a convenience yield on liquidity which drives the required return down. Such a convenience yield is necessary to explain why liquid assets are held although they earn low returns.

The representative agent's problem is to choose consumption, external financing, discretionary payouts, liquid balances, committed payouts, and investment in order to maximize discounted expected utility subject to two budget constraints, one for the consumer sector and one for the corporate sector. The economy is subject to two shocks, $A_{K}$, which determines the current productivity of capital, and $A_{I}$ which determines the current investment opportunity. These shocks follow an exogenous Markov chain.

We study the problem in its recursive form, and write the agent's problem as:

\footnotetext{
${ }^{13}$ See, for example, Eisfeldt (2004) for a model where the degree of adverse selection varies with aggregate economic conditions. See Rampini (2004), Hertzberg (2005), and Philippon (2005) for models where agency costs vary over the business cycle. See Korajczyk and Levy (2003) for evidence on business cycle variation in capital structure due to financial constraints, and Rampini and Eisfeldt (2006) for evidence that financial frictions are larger in recessions.
} 


$$
v(Z) \equiv \max _{\left(C, \hat{F}, E, L^{\prime}, D^{\prime}, I\right) \in \mathbb{R}_{+}^{5} \times \mathbb{R}} u(C)+\beta E\left[v\left(Z^{\prime}\right) \mid Z\right]
$$

subject to

$$
\begin{aligned}
C+\hat{F} & \leq D+E \\
I+D+E+L^{\prime}+\mathcal{M}(\hat{F})+\mathcal{J}\left(A_{K} K^{\alpha}-D\right) & \leq A_{K} K^{\alpha}+L\left(1+\rho_{L}\right)+\hat{F}
\end{aligned}
$$

where $Z \equiv\left(K, L, D, A_{K}, A_{I}\right)$ is the vector of state variables and $Z^{\prime}$ the vector of state variables next period. For all variables, “'” denotes next period values.

The law of motion for capital is described by:

$$
K^{\prime}=(1-\delta) K+A_{I} I
$$

Thus, a higher $A_{I}$ denotes an investment opportunity since it implies that investment in new capital goods is more productive.

The consumer sector budget constraint in words states that consumption $(C)$ plus external funds sent to the corporate sector $(\hat{F})$ must be less than or equal to funds sent to the consumer sector from the corporate sector in the form of discretionary payments $(E)$ and committed payments $(D)$. The corporate sector budget constraint in words states that investment $(I)$ plus funds sent to the consumer sector in the form of committed payments $(D)$ plus discretionary payments $(E)$ plus accumulation of liquid balances $\left(L^{\prime}\right)$ plus the Myers cost on external funds $(\mathcal{M}(\cdot))$ plus the Jensen cost $(\mathcal{J}(\cdot))$ on internal funds must be less than or equal to output $\left(A_{K} K^{\alpha}\right)$ plus accumulated liquidity $\left(L\left(1+\rho_{L}\right)\right)$ plus external funds from the consumer sector $(\hat{F})$.

The Myers operator, $\mathcal{M}(\cdot)$, captures the cost of external finance. Funds sent into the corporate sector must be monitored so that they are not wasted, and this monitoring is costly. The Myers cost can be reduced by ensuring adequate funds for investment through accumulated liquidity balances $L$, however, the opportunity cost is using fewer funds for investment and/or consumption. The Jensen operator, $\mathcal{J}(\cdot)$, captures the agency cost of keeping cash flow inside the firm. Costly monitoring is also necessary to ensure that funds generated in the corporate sector are not wasted. This cost can be reduced in the following period by choosing a larger committed payout $D^{\prime}$. 
However, since the committed payout is chosen before next period's productivity and investment opportunities are realized, too large a committed payout can lead the firm to need to raise costly external finance to meet such commitments. We use the letter " $D$ " to denote committed "debt" payouts, but have in mind other committed payouts such as wages and other fixed costs of production. The financial and operating leverage created by such fixed costs may lead to shortfalls even when there are no productive investment opportunities. Such payments work like a technology which, by committing to $D$ one period ahead, allows consumers to costlessly acquire funds from the corporate sector. Thus, any new flows into the corporate sector, from internal or external sources, must be monitored. Stocks of liquid assets, on the other hand, do not incur Jensen costs in our model and can be costlessly reallocated between the consumer and the corporate sector. We have in mind that liquid assets are allocated to a financial intermediary where their existence is hence known and measurable, so that they can be costlessly monitored. In fact, this is what is unique about liquid assets. Liquid balances earn a return of $\rho_{L} \cdot{ }^{14}$

To a standard real business cycle model, we have added: investment opportunities, Jensen costs and payout commitments, Myers costs, and liquidity accumulation. It is worthwhile to briefly review the motivation for each departure from the standard model. Using shocks to $A_{I}$ allows us to separate investment opportunities from cash flow shocks coming from $A_{K}$. This is useful in order to disentangle true investment opportunities from forces such as consumption smoothing and income effects coming from productivity shocks which also drive investment. Moreover, if investment opportunities come from persistence in productivity, then cash flows and investment opportunities will coincide. Similarly, separating investment opportunities from cash flow shocks allows one to study the different effects of states in which the corporate sector is constrained (i.e., has good investment opportunities but low funds) vs. distressed (has no investment opportunities, but high committed payouts relative to operating cash flow). Jensen costs and the payout commitments that alleviate them

\footnotetext{
${ }^{14}$ We have studied a version of this model where liquid funds incur Jensen costs. The main difference is that, because this cost lowers the return to investing in liquid assets, for a given set of parameters, a higher $\rho_{L}$ is necessary to generate a given level of liquidity holdings.
} 
create the need for external finance. If Jensen costs are zero, the firm can costlessly retain all funds and make (also costless) discretionary payouts $E$ as desired. Payout commitments also "leverage" low cash flow shocks, which can lead to larger variation in the value of liquidity than the one implied by productivity shocks alone. Myers costs separate the consumer and corporate sector. The marginal cost of external finance will pin down the value of funds inside the corporate sector. Finally, allowing for liquidity accumulation allows us to study the level and variation in liquidity holdings and prices. Even without liquidity we can study the shadow price of funds inside the corporate sector, but we cannot study liquidity management.

We can simplify the described program as follows: Notice that since external finance is costly, the firm would never both make a discretionary payout, i.e., set $E>0$, and raise external financing, i.e., choose $\hat{F}>0$. Thus, we can define net external financing $F$ as $F \equiv \hat{F}-E$. If $F$ is positive, the firm is raising external finance, and if $\mathrm{F}$ is negative it is making discretionary payouts. The problem can then be written as follows:

$$
v(Z) \equiv \max _{\left(C, L^{\prime}, D^{\prime}, K^{\prime}, F\right) \in \mathbb{R}_{+}^{4} \times \mathbb{R}} u(C)+\beta E\left[v\left(Z^{\prime}\right) \mid Z\right]
$$

subject to

$$
\begin{gathered}
C \leq D-F \\
D-(F-\mathcal{M}(F)) \leq A_{K} K^{\alpha}-\left(L^{\prime}-L\left(1+\rho_{L}\right)\right)-\left(K^{\prime}-(1-\delta) K\right) A_{I}^{-1}-\mathcal{J}\left(A_{K} K^{\alpha}-D\right)
\end{gathered}
$$

where, with some abuse of notation, we again use $\mathcal{M}$ to denote the Myers operator but specify that $\mathcal{M}(F) \equiv 0$ if $F \leq 0$. We also use $K^{\prime}$ here as the choice variable instead of $I$ (which has been substituted out using the law of motion for capital). This formulation reduces the state space and is preferable for numerical implementation. Using subscripts to denote derivatives, the first order conditions then read

$$
\begin{aligned}
u_{C}(C) & =\mu_{C} \\
\mu_{C} & =\mu_{L}\left(1-\mathcal{M}_{F}(F)\right) \\
\mu_{L} & =\beta E\left[v_{L}\left(Z^{\prime}\right) \mid Z\right] \\
0 & =\beta E\left[v_{D}\left(Z^{\prime}\right) \mid Z\right] \\
\mu_{L} A_{I}^{-1} & =\beta E\left[v_{K}\left(Z^{\prime}\right) \mid Z\right]
\end{aligned}
$$


where $\mu_{C}$, the multiplier on the budget constraint of the consumer sector, is the shadow value of resources outside the firm and $\mu_{L}$, the multiplier on the budget constraint of the corporate sector, is the shadow value of resources inside the firm and hence the shadow value of liquidity. The envelope conditions are

$$
\begin{aligned}
& v_{L}(Z)=\mu_{L}\left(1+\rho_{L}\right) \\
& v_{D}(Z)=\mu_{C}-\mu_{L}\left(1+\mathcal{J}_{D}\left(A_{K} K^{\alpha}-D\right)\right) \\
& v_{K}(Z)=\mu_{L}\left(\alpha A_{K} K^{\alpha-1}-\mathcal{J}_{K}\left(A_{K} K^{\alpha}-D\right)+(1-\delta) A_{I}^{-1}-\mathcal{M}_{K}(F)\right),
\end{aligned}
$$

where in the envelope condition for capital we have allowed for a (notationally suppressed) dependence of Myers and Jensen costs on the level of free cash flow and external finance relative to the aggregate capital stock.

Combining equations (9), (11), and (14) we have the following Euler equation which governs liquidity accumulation and payout commitments:

$$
0=\beta E\left[\mu_{L}^{\prime}\left(-\mathcal{J}_{D}\left(A_{K}^{\prime} K^{\prime \alpha}-D^{\prime}\right)-\mathcal{M}_{F}\left(F^{\prime}\right)\right]\right.
$$

Thus, accumulation of liquidity and payout commitments are chosen to balance the expected cost of external finance (à la Myers) and the expected cost of free cash flow (à la Jensen).

The relative price of liquidity is given by rearranging equation (9), where $\mu_{L}$ is the shadow price of liquidity, and $\mu_{C}$ is the shadow price of consumption goods. We have,

$$
\frac{\mu_{L}}{\mu_{C}}=\frac{1}{1-\mathcal{M}_{F}(F)} \geq 1
$$

which implies that $\mu_{C} \leq \mu_{L}$. This condition holds with equality if and only if $F \leq 0$, meaning that the corporate sector is paying out funds. Otherwise, there is a liquidity premium. The value of aggregate liquidity is one if the firm is not raising external funds, and is increasing in the amount of external financing raised. In other words, the value of aggregate liquidity is determined by the financing shortfall in the corporate sector. We will show in section 2.3 below, using a parameterized version of this model, that firms raise external funds whenever investment opportunities are good, or output is low. The value of aggregate liquidity is highest when output is low, but investment opportunities are good. 
To illustrate the returns to investing in liquid assets and (illiquid) physical capital, it is useful to specify the Myers and Jensen operators. We operationalize these using:

$$
\mathcal{M}(\cdot) \equiv \frac{\phi_{\mathcal{M}}}{2}\left(\frac{F}{K}\right)^{2} K
$$

and

$$
\mathcal{J}(\cdot) \equiv \frac{\phi_{\mathcal{J}}}{2}\left(\frac{A_{K} K^{\alpha}-D}{K}\right)^{2} K,
$$

where $(M)(\cdot)=0$ if $F<0$ and $(J)(\cdot)=0$ if $A_{K} K^{\alpha}-D<0$. We think that scaling external finance and free cash flow by capital makes sense because monitoring a large flow of funds when the corporate sector is relatively small is probably more costly than monitoring an equivalent flow when the corporate sector is large. The cost parameters $\phi_{\mathcal{M}}$ and $\phi_{\mathcal{J}}$ are chosen so that the corporate sector experiences shortfalls (it is sometimes optimal to raise external finance) but also occasionally makes discretionary payouts.

There is a tradeoff between investing in capital and accumulating liquidity which is governed by the relative expected returns to each type of investment. Thus, to generate corporate demand for liquidity in a model with capital accumulation, it must be the case that in some states the expected return on investing in liquid assets exceeds that of investing in productive capital. In other words, the value of liquid assets for hedging states with a mismatch between investment opportunities and available funds will induce a convenience yield on liquidity only if there are states where it is better to hedge with liquid assets than by simply over accumulating real capital itself. Over accumulating physical capital can be an inferior hedging strategy in this model for two reasons: First, cash flows from physical capital are risky, and may be low when investment opportunities arise. Second, cash flows from output are subject to Jensen costs. We formalize the comparison of the returns to physical capital and liquidity accumulation by comparing the analytical characterization for the expected returns to each, and then study the realization of these relative expected returns as a function of the aggregate state in a simulation of the model economy. Our returns are a version of production based asset pricing, as in Cochrane (1991, 1996). 
The return on liquid assets is given by:

$$
R_{L}\left(Z^{\prime}\right) \equiv \frac{1-\mathcal{M}_{F}(F)}{1-\mathcal{M}_{F}\left(F^{\prime}\right)}\left(1+\rho_{L}\right) .
$$

The Euler equation for liquidity implies that

$$
1 \geq E\left[\frac{\beta u_{C}\left(C^{\prime}\right)}{u_{C}(C)} R_{L}\left(Z^{\prime}\right) \mid Z\right]
$$

with equality whenever $L^{\prime}>0$. The conditional expected return is increasing in the expected marginal Myers cost tomorrow relative to today; if the marginal cost of external finance is expected to be higher tomorrow than it is today, then the corporate sector will choose to accumulate liquidity which will drive the price of liquid assets up and the expected returns down.

The expected return on capital is given by:

$$
\begin{aligned}
R_{K}\left(Z^{\prime}\right) & \equiv \frac{1-\mathcal{M}_{F}(F)}{1-\mathcal{M}_{F}\left(F^{\prime}\right)} \\
& \times\left(\frac{A_{K}^{\prime} \alpha K^{\prime \alpha-1}\left(1-\phi_{\mathcal{J}} \frac{A_{K}^{\prime} K^{\prime \alpha}-D^{\prime}}{K^{\prime}}\right)+\frac{\phi_{\mathcal{J}}}{2}\left(\frac{A_{K}^{\prime} K^{\prime \alpha}-D^{\prime}}{K^{\prime}}\right)^{2}+(1-\delta) A_{I}^{\prime-1}+\frac{\phi_{\mathcal{M}}}{2}\left(\frac{F^{\prime}}{K^{\prime}}\right)^{2}}{A_{I}^{-1}}\right)
\end{aligned}
$$

and the Euler equation implies that

$$
1=E\left[\frac{\beta u_{C}\left(C^{\prime}\right)}{u_{C}(C)} R_{K}\left(Z^{\prime}\right) \mid Z\right] .
$$

As with liquid balances, the conditional expected return is increasing in the expected marginal Myers cost tomorrow relative to today. However, the return to capital also depends positively on the investment opportunity today relative to tomorrow, and the expected productivity shock tomorrow, and negatively on the level of the capital stock because of the concavity of the production function. The return is decreasing in the resulting Jensen cost from higher free cash flow at higher capital stocks. Finally, since marginal Myers and Jensen costs are functions of external finance and free cash flow relative to capital, increasing capital lowers these marginal costs and increases the return to capital slightly. These returns to investing in liquid assets vs. real assets will determine how investment opportunities are hedged. 


\subsection{Model where Cash Flows Arrive in the Consumer Sector}

We develop a version of our model where cash flows arrive in the consumer sector to illustrate the role of the natural supply of liquidity from internal cash flows from current output in generating a countercyclical liquidity premium. The agent's problem in this economy can be written as follows:

$$
v(Z) \equiv \max _{\left(C, L^{\prime}, K^{\prime}, F\right) \in \mathbb{R}_{+}^{3} \times \mathbb{R}} u(C)+\beta E\left[v\left(Z^{\prime}\right) \mid Z\right]
$$

subject to

$$
\begin{gathered}
C \leq A_{K} K^{\alpha}-F \\
\left(L^{\prime}-L\left(1+\rho_{L}\right)\right)+\left(K^{\prime}-(1-\delta) K\right) A_{I}^{-1} \leq F-\mathcal{M}(F)
\end{gathered}
$$

where we again use $K^{\prime}$ as the choice variable instead of $I$ (which has been substituted out using the law of motion for capital). Thus, the difference to the model with cash flows arriving in the corporate sector is that the budget constraint on the consumer sector reflects the fact that output arrives to consumers; all current cash flows are paid out. There is no role for payout policy, however firms may accumulate liquidity to manage the cost of external finance.

The first order conditions then read

$$
\begin{aligned}
u_{C}(C) & =\mu_{C} \\
\mu_{C} & =\mu_{L}\left(1-\mathcal{M}_{F}(F)\right) \\
\mu_{L} & =\beta E\left[v_{L}\left(Z^{\prime}\right) \mid Z\right] \\
\mu_{L} A_{I}^{-1} & =\beta E\left[v_{K}\left(Z^{\prime}\right) \mid Z\right]
\end{aligned}
$$

where again $\mu_{C}$ is the shadow value of resources outside the firm and $\mu_{L}$ is the shadow value of resources inside the firm and hence the shadow value of liquidity. The envelope conditions are

$$
\begin{aligned}
v_{L}(Z) & =\mu_{L}\left(1+\rho_{L}\right) \\
v_{K}(Z) & =\mu_{C} \alpha A_{K} K^{\alpha-1}+\mu_{L}\left((1-\delta) A_{I}^{-1}-\mathcal{M}_{K}(F)\right) .
\end{aligned}
$$

Note relative price of liquidity is again

$$
\frac{\mu_{L}}{\mu_{C}}=\frac{1}{1-\mathcal{M}_{F}(F)} \geq 1 .
$$


Since all cash flows from output arrive in the consumer sector, firms will always need to raise external finance if investment above the level of accumulated liquidity is undertaken. Thus, the value of aggregate liquidity exceeds one as long as investment is above the level of accumulated liquidity. Variation in the value of aggregate liquidity is almost entirely driven by investment, since internal funds from output are always zero. Since investment is procyclical, so is the liquidity premium in this model with forced payouts. This illustrates the role of the natural supply of liquidity in the corporate sector in determining variation in the value of liquidity, as well as the role of Jensen costs in the tradeoff determining liquidity accumulation. We argue that, importantly, what is missing from the model with cash flows arriving in the consumer sector is variation in the "natural supply" of liquidity. Since cash flows and hence internal funds are high when productivity is high, the natural supply of liquidity is procyclical. Thus, our model can generate countercyclical liquidity premia consistent with empirical observations. ${ }^{15}$

\subsection{Decomposition of Cash Flows}

To compare the model output to the data, and to guide our empirical work, it is useful to arrange the budget constraint of the corporate sector to describe the sources and uses of funds. To distinguish inflows and outflows we revert to using $\hat{F}$ when $F$ is positive and $E$ when $F$ is negative. The decomposition of cash flows into internal funds and external funds, on the one hand, and uses of funds on the other yields:

$$
\underbrace{A_{K} K^{\alpha}+L\left(1+\rho_{L}\right)-D-\mathcal{J}\left(A_{K} K^{\alpha}-D\right)}_{\text {Internal Funds }} \underbrace{-E+\hat{F}-\mathcal{M}(\hat{F})}_{\text {External Funds }} \geq \underbrace{I+L^{\prime}}_{\text {Uses of Funds }}
$$

Moreover, this budget constraint will hold with equality. Decomposing the model cash flows into cash flows from operations $\left(C F_{O}\right)$, cash flow to capital $\left(C F_{K}\right)$, cash flow to equity holders $\left(C F_{E}\right)$, and cash flow to debt holders $\left(C F_{D}\right)$ yields an identity analogous to that found in the US flow of funds and in the Compustat cash flow

\footnotetext{
${ }^{15}$ In a related framework, Gomes, Yaron, and Zhang $(2003,2005)$ show that introducing costly external finance into a business cycle model with capital adjustment costs generates a procyclical premium on external finance.
} 
statements:

$$
\underbrace{A_{K} K^{\alpha}-\mathcal{J}\left(A_{K} K^{\alpha}-D\right)}_{\mathrm{CF}_{O}}-\underbrace{\left(I+\left(L^{\prime}-L\left(1+\rho_{L}\right)\right)\right)}_{\mathrm{CF}_{K}}=\underbrace{E-(\hat{F}-\mathcal{M}(\hat{F}))}_{\mathrm{CF}_{E}}+\underbrace{D}_{\mathrm{CF}_{D}}
$$

\subsection{Simulation}

We parameterize our model and study the implications for the value of aggregate liquidity as a function of productivity and investment opportunity shocks. We find that we can generate liquidity accumulation even if the expected return on liquid assets is over three percent lower than that on capital, and that the liquidity premium is countercyclical. We also examine the policy functions for liquidity accumulation, external financing, and payout policy. Thus, our model can be used to guide empirical studies of the effect of firms' financial positions and actions on the value of liquidity.

While have not yet fully calibrated our model, we use standard parameter values where available. Table 1 contains our parameterization. We assume that investment opportunities $A_{I}$ and productivity shocks $A_{K}$ can each take on two values, $\mathrm{H}$ and L, and specify both shock processes to be i.i.d. and uncorrelated in this section, for exposition.

We chose an unconditional return on liquidity which was close to zero, but which implied positive accumulation. Our results concerning variation in the expected return on liquidity and the liquidity premium do not depend on $\rho_{L}>0$, however, given the rest of our chosen parameter values, liquidity accumulation is zero if $\rho_{L}=0$. We set the unconditional expected return on liquid balances $\rho_{L}$ to be $1 \%$. This return determines the payoffs generated by liquid asset holdings, but the conditional expected returns and prices are determined by this payoff along with the stochastic discount factor and shadow value of liquid funds in the corporate sector. Given our choice for beta (see table 1) the unconditional expected return on capital is about $4.18 \%$ (which is approximately $1 / \beta-1=4.17 \%$ ). Thus, since the unconditional expected return on liquid balances is $1 \%$, the conditional variation in these relative returns will be key for generating liquidity accumulation. There will be some states where the return to liquidity accumulation exceeds that of investing in physical capital. It is in states where investment opportunities are low, and the level of the existing 
capital stock is high (particularly when productivity is low), that the expected return to investing in liquid assets exceeds that of investing in productive capital. In turn, when investment opportunities are high and productivity (and hence cash flows) are low, the value of liquidity exceeds its intrinsic value, driving up the price and driving down expected returns.

We illustrate the demand for liquidity in our model by plotting the expected returns to liquid assets and productive capital, along with some of the policy functions, as a function of the aggregate state and the level of the capital stock. Figure 3 plots conditional expected returns as a function of aggregate capital for the four exogenous states. In this and subsequent figures, the four panels represent realizations of the exogenous state $\left(A_{I}, A_{K}\right)$, and for each level of capital along the x axis, we integrate over the other two state variables, the liquidity stock, $L$, and committed payouts, D. We have smoothed each series using the Hodrick Prescott (1997) filter. The two left hand panels of figure 3 show that when there is an investment opportunity, the expected return on capital increases and, since liquid assets can costlessly fund investment, the price of liquidity increases, pushing the expected return on liquidity down. Thus, liquidity accumulation is dominated by investment in capital, and existing liquidity is used to fund investment. On the other hand, when there is no investment opportunity, the price of capital is relatively high and hence the return on capital is low. The price of liquidity, on the other hand, is low, pushing the expected return on liquidity up. Thus, for higher levels of capital (where lower marginal productivity of capital pushes the return to investment down), liquidity accumulation dominates investment in capital and the corporate sector increases its stock of liquid assets.

Table 2 displays conditional prices and returns. The first column displays the value of aggregate liquidity, $\mu_{L}$, relative to the value of consumption goods $\mu_{C}$. This ratio expresses the value of funds inside the corporate sector relative to funds in the consumer sector. When this ratio exceeds one, there is a premium on liquidity relative to consumption goods. The liquidity premium is increasing in investment opportunities and decreasing in the productivity or cash flow shock, hence it is countercyclical. The premium is about two times higher when productivity is low than 
when it is high. The second column displays the conditional expected return on liquidity, which is increasing in productivity and decreasing in investment opportunities (the higher price in low productivity states, and states with investment opportunities, pushes down the return in those states). Column three shows the conditional expected return on capital. This return is increasing in productivity and, naturally, in investment opportunities.

The policy functions for liquidity accumulation, investment, external finance, and payout commitments are graphed as a function of the aggregate state and the level of the capital stock in figures 4 to 6 . We have again integrated over the values for $L$ and $D$ conditional on $K$ and used the HP filter to smooth the series. The accumulation of liquid assets is graphed in figure 4. Liquidity is accumulated only when its expected return dominates that of productive capital. There is no accumulation of liquidity when there is an investment opportunity since the return to investing in capital is high in these states. If there is no investment opportunity, liquidity accumulation is increasing in the level of the existing capital stock, and in the productivity of capital. This makes sense since when productivity is high and capital is abundant, returns to additional capital are low but excess cash flows are high.

Figure 4 also plots the policy for investment in productive capital, and shows that aggregate investment is always positive, and is increasing in $A_{I}$ and $A_{K}$. Investment is higher when there are investment opportunities. When there is no investment opportunity, investment is decreasing in the level of the existing capital stock. The tradeoff and substitution between investing in liquidity and investing in capital can be seen clearly in the right hand panels of the figure, where investment opportunities are low. Investment is also higher when productivity (and hence realized internal cash flows) are high due to the consumption smoothing effect. The fact that $A_{K}$ shocks are i.i.d. and investment is still procyclical illustrates the strength of this effect, which is an important driver of procyclical investment even in standard business cycle models with persistent shocks.

In addition to implications for liquidity management and investment, our model also has implications for policies governing external finance and payouts. Figure 5 plots external finance. External finance is increasing in investment opportunities, $A_{I}$, 
and decreasing in productivity $A_{K}$ since high productivity leads to high internal cash flow. There are discretionary payouts only when productivity is high and there is no investment opportunity. Figure 6 plots payout commitments, which are increasing in capital, productivity, and investment opportunities, since all lead to higher investment and hence higher cash flow tomorrow. Promising higher committed payouts can alleviate Jensen costs by reducing such free cash flow.

Table 3 displays the conditional means of the policy function and summarizes the variation in investment, liquidity accumulation, external financing, and payout commitments. Column one displays the choice for the capital stock, and column seven displays investment. Both are increasing in investment opportunities and productivity. Investment is clearly procyclical in our model, even though productivity shocks are i.i.d. and liquid assets are available as consumption smoothing instruments. This is because the natural supply of internal funds for investment, namely free cash flow, is high in good times and this makes investment less costly since external finance is not needed. Column two displays the choice for liquid assets, which are positive only when there is no investment opportunity, and are increasing with productivity in these states. Column five displays net liquidity accumulation, and shows that only when productivity is high and there is no investment opportunity are liquid asset balances increased. Column four shows the choice for committed payouts, which are increasing in productivity and investment opportunities since both of these lead to higher investment and hence higher output and cash flows in the following period. Column three shows external financing. Only when productivity is high but there are no investment opportunities are discretionary payouts made, and otherwise external finance is raised. Despite good investment opportunities when the aggregate state is $\left(A_{K}, A_{I}\right)=(H, H)$, firms need not raise as much external finance because the supply of natural liquidity is high due to high productivity. We have chosen the cost parameters $\phi_{\mathcal{M}}$ and $\phi_{\mathcal{J}}$ so that the corporate sector experiences shortfalls (it is sometimes optimal to raise external finance) but also occasionally makes discretionary payouts. Because our shocks are i.i.d., this means that the resulting levels of external finance and discretionary payouts are relatively small. We will show later that external finance is indeed quite small empirically. Columns six through eight display output, 
investment, and consumption. Consumption relative to output is decreasing in investment opportunities, and in productivity. This is in contrast to standard models (e.g. Campbell (1996)). Comparing consumption relative to output illustrates how our modeling choice for investment opportunities combined with committed payouts (operating or financial leverage) and costly external finance alleviates the income effect resulting from their arrival.

Table 4 displays the circulation of funds in the model economy. The cash flows from operations, cash flows to capital, cash flows to "equity" (i.e., discretionary financing), and cash flow to "debt" (i.e., committed payouts) are shown. The variation in these conditional means will be useful when comparing the model output to empirical counterparts.

Figures 7 plots some time series from a simulation of this economy. The top two panels plot the process for the value of aggregate liquidity and the financing shortfall. The correlation between these two series is 0.7 , which is (not surprisingly) significant at the $1 \%$ level. The third panel shows the close relationship between discretionary payouts or external finance and the liquidity premium, or premium on internal funds in the corporate sector. The difference between the middle two panels is committed payouts, $D$; adding $D$ to the series in the third panel would make the two series equal according to the identity governing the circulation of funds. Finally, the bottom panel plots liquidity accumulation, which is high when the liquidity premium is low since that drives up the expected return on liquid assets.

The three main implications of the model which we will explore empirically are: First, that the value of aggregate liquidity, or the liquidity premium, is increasing in the degree of the corporate sector's financing shortfall. Second, financing shortfalls are more likely to occur when productivity, and hence cash flows, are low since this reduces the supply of natural liquidity. These two implications together generate a third implication, which is that the liquidity premium is countercyclical. Our empirical application is preliminary, and we begin by focusing on the first implication. 


\section{Empirics}

Using US Flow of Funds data and Compustat data, we construct aggregate cash flow identities which mirror those from the model in section 2.2. We have that cash flow from operations less cash flow to capital equals cash flow to equity holders plus cash flow to debtholders.

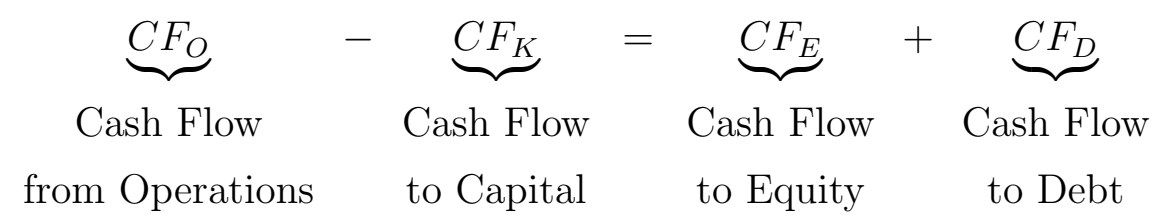

where all variables are net and cash flow from operations, $C F_{O}$, is revenues less expenses; cash flow to capital, $C F_{K}$, is investment in productive capital plus investment in liquid assets plus acquisitions less asset sales; cash flow to equityholders, $C F_{E}$ includes issuances, repurchases and dividends; and cash flow to debtholders, $C F_{D}$ includes issuances, principal and interest payments. Figure 8 illustrates the circulation of funds governing this empirical identity.

We begin by constructing series for the corporate sector as a whole in the flow of funds and Compustat data. Figure 9 graphs the flow of funds series for the four elements of the cash flow identity. A shortfall occurs when $C F_{K}>C F_{O}$, and this is when we would expect the value of aggregate liquidity to be high. More generally, the model predicts that a smaller $C F_{O}-C F_{K}$ should result in a higher value of aggregate liquidity. True aggregate shortfalls are rare, however, they do occur and there is clear variation in $C F_{O}-C F_{K}$ at the cyclical frequency. Figure 10 graphs the elements of the cash flow identity as a fraction of $C F_{O}$, which allows one to clearly see the occurences of the financing shortfalls. Recently, considerable attention has been focused on the growth in corporate cash balances. Bates, Kahle, and Stulz (2006) document that the average cash to assets ratio for US industrial firms increased by $129 \%$ from 1980 to 2004. The bottom panel of figure 10 breaks out cash flows to capital into flows to physical capital and into liquid assets. Our documentation of the flows of investment into liquid vs. illiquid capital shows that flows have also been increasing, and also that there is important business cycle variation in these flows 
in addition to the growing trend. The fact that there is considerable business cycle variation in these flows supports the idea that corporate savings might drive variation in the value of liquid assets over the business cycle. In terms of measuring shortfalls, comparing $C F_{O}$ to the flows to physical capital only may more accurately identify true financing shortfalls.

Figure 11 plots the time series of financing shortfalls. The top panel plots the aggregate shortfall series from the flow of funds and from Compustat. The two series have a positive correlation of 0.7 , which is statistically significant at the $1 \%$ level. The advantage of looking at the Compustat data (although it is a shorter time series, and consists only of publicly traded firms), is that it can be disaggregated. The aggregate series sum over each term in the identity in equation (29) and hence net out lots of firm level shortfalls. Thus, the aggregate series wash out cases where many firms may have shortfalls, but other firms have offsetting surpluses. As long as there is costless reallocation within the corporate sector (as in our model) this should not matter, but, potentially there do exist such reallocation frictions, and these frictions may drive liquidity premia up further than the ones between the corporate and consumer sector do alone. The bottom panel of figure 11 plots the aggregate shortfall vs. the sum of firm level shortfalls (i.e. the sum of $C F_{O}-C F_{K}$ where this difference is negative). The difference between these two series is then the sum of firm level surpluses. Not surprisingly, while the aggregate shortfall is rarely positive, the sum of shortfalls can be large, and has been growing over time. Interestingly, the two series display very similar time series variation, which means that aggregate shortfalls are not driven by low surpluses, but by large firm level shortfalls. The correlation between the two series is 0.66 and this is significant at the $1 \%$ level. This implies that the aggregate series will capture similar variation in shortfalls and hence implied liquidity premia to the disaggregated series, even if the level of the implied liquidity premium would be higher in a model with frictions within the corporate sector.

Finally, The model economy generates a correlation of 0.7 between shortfalls and the value of aggregate liquidity. For the flow of funds data, the correlation between the HP filtered CP-Bill spread and the similarly transformed aggregate shortfall is positive 0.2. Interestingly, the shortfall series appears to lead the CP-Bill 
spread (see for example, the comparison between the largest shortfall and the largest realization of the CP-Bill spread in 1973 and 1974, respectively). A regression of the cyclical component of the orthogonalized CP-Bill spread on current and lagged similarly filtered financing shortfalls show that this is the case. There is a strong and statistically significant relationship between the CP-Bill spread and the lagged shortfall. Table 5 displays the results from regressions of the CP-Bill spread on financing shortfalls and its lags in data generated by the model and flow of funds data. In both cases, shortfalls and its lags explain about $50 \%$ of the variation in the CP-Bill spread, but the lead lag relationship is slightly different between the two. Figure 12 plots the contemporaneous and lead-lag correlation between shortfalls and the cyclical component of the error term in from a regression of the CP-Bill spread on the Baa-Aaa corporate bond yield spread. Clearly, the two series are positively correlated. Again, it is apparent that the shortfall series leads the (orthoganolized) CP-Bill spread.

This empirical work is still preliminary. The spread between commercial paper and treasury bills may be driven by monetary effects absent in our real model. Moreover, there is the issue of how to filter the series which are trending but take on negative values. As discussed, it may be better to comparing $C F_{O}$ to the flows to physical capital only to more accurately identify true financing shortfalls. Moreover, the shocks in the model should be persistent to match the dynamics of their empirical counterparts, and we have assumed them to be i.i.d. for exposition.

\section{Conclusion}

This paper studies the relationship between firm finance and the value of liquidity. Commonly used empirical measures of liquidity are often atheoretical, or based on high frequency microstructure frictions. Instead, we attempt to use a model of aggregate corporate and consumer behavior to guide our measurement of aggregate liquidity. The model suggests that the value of liquidity should be high when firms have uses for funds (investment opportunities), but lack internal funds (they have low operating cash flows). Indeed, the value of aggregate liquidity is countercyclical 
in our model. This is due to financing shortfalls, or the scarcity of natural liquidity in the corporate sector when cash flows are low. The model also generates a convenience yield on liquidity; it can be used to fund investment when such natural liquidity is low. This convenience yield leads to liquidity accumulation even when the return to liquidity is significantly lower than that on capital. 


\section{References}

Aiyagari, S. Rao, and Mark Gertler, 1991, Asset returns with transactions costs and uninsured individual risk, Journal of Monetary Economics 27, 311-331.

Albuquerque, Rui, and Neng Wang, 2005, Agency conflicts, investment and asset pricing, Working Paper.

Allen, Franklin, and Douglas Gale, 2004, Financial fragility, liquidity and asset prices, Journal of European Economic Association 2, 1015-1048.

Bates, Thomas W., Kathleen M. Kahle, and René M. Stulz, 2006, Why do U.S. firms hold so much more cash than they used to? Working Paper.

Bernanke, Ben, Mark Gertler, and Simon Gilchrist, 1996, The financial accelerator and the flight to quality, Review of Economics and Statistics 78, 1-15.

Bernanke, Ben, Mark Gertler, and Simon Gilchrist, 1999, The financial accelerator in a quantitative business cycle framework, in John Taylor and Michael Woodford, eds.: Handbook of Macroeconomics (North Holland, Amsterdam).

Campbell, John Y., 1996, Understanding risk and return. Journal of Political Economy 104, 298-345.

Cochrane, John H. (1991). "Production-based asset pricing and the link between stock returns and economic fluctuations," Journal of Finance 46, 209-237.

Cochrane, John H. (1996). "A cross-sectional test of an investment-based asset pricing model," Journal of Political Economy 104, 572-621.

Constantinides, George M., 1986, Capital market equilibrium with transaction costs, Journal of Political Economy 94, 842-862.

Danthine, Jean-Pierre, and John B. Donaldson, 2001, What have we learned from the real business cycle research programme? in J. Dréze, ed. Advances in Macroeconomic Theory, Palgrave. 
Diamond, Douglas W., and Philip H. Dybvig, 1983, Bank runs, deposit insurance, and liquidity, Journal of Political Economy 91, 401-419.

Dow, James, Gary Gorton, and Arvind Krishnamurthy, 2005, Equilibrium investment and asset prices under imperfect corporate control, American Economic Review 95.

Duffie, Darrell, Nicolae Gârleanu, and Lasse Pedersen, 2005, Over-the-counter markets, Econometrica 73, 1815-1847.

Eisfeldt, Andrea L., 2004, Endogenous liquidity in asset markets, Journal of Finance 59, 1-30.

Eisfeldt, Andrea L., 2007, Smoothing with liquid and illiquid assets, Journal of Monetary Economics 54, 5721586.

Eisfeldt, Andrea L., and Adriano A. Rampini, 2006, Capital reallocation and liquidity, Journal of Monetary Economics 53, 369-399.

Fisher, Jonas D. M., 2006, The Dynamic effects of neutral and investment-specific technology shocks, Journal of Political Economy 114, 413-451.

Froot, Kenneth, David Scharfstein, and Jeremy Stein, 1994, A Framework for risk management, Harvard Business Review, 91-102.

Gârleanu, Nicolae, and Lasse Pedersen, 2004, Adverse selection and the required return, Review of Financial Studies 17, 643-665.

Heaton, John, and Deborah Lucas, 1996, Evaluating the effects of incomplete markets on risk sharing and asset pricing, Journal of Political Economy 104, 443487.

Gomes, Joao, Amir Yaron, and Lu Zhang, 2003, Asset prices and business cycles with costly external finance, Review of Economic Dynamics, forthcoming.

Gomes, Joao, Amir Yaron, and Lu Zhang, 2005, Asset pricing implications of firms' financing constraints, Review of Financial Studies, forthcoming. 
Gorton, Gary, and Lixin Huang, 2004, Liquidity, efficiency, and bank bailouts, American Economic Review 94, 455-483.

Greenwood, Robin, 2005, Aggregate corporate liquidity and stock returns, Working Paper.

Hennessy, Christopher, and Toni Whited, 2005, Debt dynamics, Journal of Finance 60, 11291165.

Hertzberg, Andrew, 2005, Managerial Incentives, Misreporting, and the Timing of Social Learning: A Theory of Slow Booms and Rapid Recessions, Working Paper.

Hodrick, Robert J., and Edward C. Prescott, 1997, Postwar U.S. business cycles: An Empirical investigation, Journal of Money, Credit and Banking 29, 1-16.

Holmström, Bengt, and Jean Tirole, 1996, Modeling aggregate liquidity, AEA Papers and Proceedings 86, 187-191.

Holmström, Bengt, and Jean Tirole, 1998, Private and public supply of liquidity, Journal of Political Economy 106, 1-40.

Holmström, Bengt, and Jean Tirole, 2001, LAPM: A liquidity-based asset pricing model, Journal of Finance 56, 1837-1867.

Huang, Ming, 2003, Liquidity shocks and equilibrium liquidity premia, Journal of Economic Theory 109 104-129.

Jensen, Michael, 1986, The agency costs of free cash flow: Corporate finance and takeovers, American Economic Review 76 (2), 323-330.

Jensen, Michael, 1993, The modern industrial revolution, exit, and the failure of internal control systems, Journal of Finance 48, 831-880.

Kiyotaki, Nobuhiro, and John H. Moore, 1997, Credit cycles, Journal of Political Economy 105, 211-48. 
Kiyotaki, Nobuhiro, and John H. Moore, 2004, Liquidity and asset prices, Working Paper, LSE.

Kiyotaki, Nobuhiro, and John H. Moore, 2005, 2002 Lawrence R. Klein lecture, Liquidity and asset prices, International Economic Review 46, 317-349.

Korajczyk, Robert, and Amnon Levy, 2003, Capital structure choice: Macroeconomic conditions and financial constraints, Journal of Financial Economics 68, 75-109.

Livdan, Dmitry, Horacio Sapriza, and Lu Zhang, 2005, Financially constrained stock returns, Working Paper.

Miller, Merton, and Franco Modigliani, 1958, The cost of capital, corporation finance, and the theory of investment, American Economic Review 48, 261-97.

Myers, Stewart C., and Nicholas S. Majluf, 1984, Corporate financing and investment decisions when firms have information that investors do not have, Journal of Financial Economics 13, 187-221.

Myers, Stewart, and Raghuram G. Rajan, 1998, The paradox of liquidity, Quarterly Journal of Economics 113, 733-771.

Papanikolaou, Dimitris, 2008, Investment-specific shocks and asset prices, Working Paper.

Philippon, Thomas, 2005, Corporate Governance over the Business Cycle, forthcoming, Journal of Economic Dynamics and Control.

Justiniano, Alejandro, Giorgio Primiceri, and Andrea Tambalotti, 2008, Investment shocks and business cycles, Working Paper.

Rampini, Adriano A., 2004, Entrepreneurial activity, risk, and the business cycle, Journal of Monetary Economics 51, 555-573.

Riddick, Leigh and Toni M. Whited, 2006, The Corporate propensity to save, Working Paper. 
Rochet, Jean-Charles, and Stéphane Villeneuve, 2004, Liquidity risk and corporate demand for hedging and insurance, Working Paper.

Stulz, René M., 1990, Managerial discretion and optimal financing policies, Journal of Financial Economics 26, 3-27.

Tirole, Jean, 2006, The theory of corporate finance, Princeton University Press.

Vayanos, Dimitri, 1998, Transactions costs and asset prices: A dynamic equilibrium model, Review of Financial Studies 11, 1-58.

Vayanos, Dimitri, 2004, Flight to quality, flight to liquidity and the pricing of risk, NBER Working Paper 10327.

Vayanos, Dimitri, and Jean-Luc Vila, 1999, Equilibrium interest rate and liquidity premium with transactions costs, Economic Theory 13, 509-539. 


\section{Data Appendix}

\section{Flow of Funds Data}

We use the quarterly data from the electronic ASCII flow of funds seasonally adjusted annual rates table F.102 available at http://www.federalreserve.gov/Releases/z1/Current/data.htm.

Quarterly annual rates are divided by four and summed to compute annual data. Refer to the coded tables for definitions and relationships between entries. Codes appear in parentheses after variable names. Interest payments, not reported in table F.102, are from NIPA table 1.14 line 25 "Net interest and miscellaneous payments" for nonfinancial corporate business. We compute $C F_{O}-C F_{K}=C F_{D}+C F_{E}$ where (item codes in parentheses):

$C F_{O}=($ Total internal funds + IVA) (FA1060000105) - Discrepancy (FA107005005) + Net dividends (FA106120005) + Trade payables (FA103170005) + Taxes payable (FA103178000) + Miscellaneous liabilities (FA103190005) - Trade receivables (FA103070005) + NIPA interest

$C F_{K}=$ Capital expenditures $(\mathrm{FA} 105050005)+$ Net acquisition of financial assets (FA104090005) - Commercial paper (FA103069100) - Mortgages (FA103065003) Trade receivables (FA103070005)

$C F_{D}=$ Commercial paper (FA103169700) + Mortgages (FA103065003) - Credit market instruments (FA104104005) + NIPA interest

$C F_{E}=$ Net dividends (FA106120005) - Net new equity issues (FA103164003)

We also decompose $C F_{K}$ into "liquid" and "illiquid" components:

$C F_{K l}=$ Net acquisition of financial assets - Commercial paper - Mortgages - Trade receivables

and

$C F_{K n l}=$ Capital expenditures 


\section{Computstat Data}

We use the industrial annual files. We compute $C F_{O}-C F_{K}=C F_{D}+C F_{E}$ by first checking which type of cash flow statement is used in each firm year (item 318), and then defining the following (item numers in parentheses):

For statments of cash flows:

$C F_{O}=$ Income before extra items $(123)+$ Depreciation and amortization $(125)+$ EI \& Discontinued Oper (124) + Deferred Taxes (126) + Equity in net loss (106) + Funds from operations: other (217) + Income taxes: accrued inc(dec) (305) + Assets \& Liab: other (net change) (307) + Accounts receivable dec(inc) (302)+ Inventory dec(inc) $(303)+$ Accounts payable inc(dec) (304) + Interest paid (net) (315)

$C F_{K}=$ Increase in investments (113) - Sale of investments (109) -Short-term invest.: change (309) + capital expenditures (128) - Sale of property, plant \& equip (107) + acquisitions (129) - Investing activities: other (310) + cash \& cash equiv inc(dec) (274) - Sale of PPE \& invest. loss(gain) (213) - Exchange rate effect (314) - Financing activities: other (312)

$C F_{E}=$ - Sale of common and pref. stock (108) + Purchase of common and pref. stock (115) + Cash dividends (127)

$C F_{D}=$ - Long-term debt issuance (111) + Long-term debt: reduction (114) - Changes in current debt (301) + Interest paid (net) (315)

For statments by source and use of funds:

$C F_{O}=$ Income before extra items $(123)+$ Depreciation and amortization $(125)+$ EI \& Discontinued Oper $(124)+$ Deferred Taxes (126) + Equity in net loss (106) + Funds from operations: other (217) + Interest expense (15)

$C F_{K}=$ Increase in investments (113) - Sale of investments (109) + capital expenditures (128) - Sale of property, plant \& equip (107) + acquisitions (129) + cash \& cash equiv inc(dec) (274) - Sale of PPE \& invest. loss(gain) (213) - Sources of funds: other $(218)+$ Uses of funds: other (219) 
$C F_{E}=-$ Sale of common and pref. stock (108)+ Purchase of common and pref. stock $(115)+$ Cash dividends (127)

$C F_{D}=$ - Long-term debt issuance (111) + Long-term debt: reduction (114) - Changes in current debt (301) + Interest expense (15)

For working capital statementes:

$C F_{O}=$ Income before extra items $(123)+$ Depreciation and amortization $(125)+$ EI \& Discontinued Oper (124) + Deferred Taxes (126) + Equity in net loss (106) + Funds from operations: other (217)+ Interest expense (15)

$C F_{K}=$ Increase in investments (113) - Sale of investments (109) + capital expenditures (128) - Sale of property, plant \& equip (107) + acquisitions (129) + cash \& cash equiv inc(dec) (274) - Sale of PPE \& invest. loss(gain) (213) + Working capital change: other (236) - Sources of funds: other (218) + Uses of funds: other (219)

$C F_{E}=-$ Sale of common and pref. stock (108)+ Purchase of common and pref. stock (115) + Cash dividends (127)

$C F_{D}=$ - Long-term debt issuance (111) + Long-term debt: reduction (114) - Changes in current debt (301) + Interest expense (15)

For cash statements by activity:

$C F_{O}=$ Income before extra items $(123)+$ Depreciation and amortization $(125)+$ EI \& Discontinued Oper $(124)+$ Deferred Taxes (126) + Equity in net loss (106) + Funds from operations: other (217) + Interest expense (15)

$C F_{K}=$ Increase in investments (113) - Sale of investments (109) + capital expenditures (128) - Sale of property, plant \& equip (107) + acquisitions (129) + cash \& cash equiv inc(dec) (274) - Sale of PPE \& invest. loss(gain) (213) - Working capital change: other (236) - Sources of funds: other (218) + Uses of funds: other (219)

$C F_{E}=-$ Sale of common and pref. stock (108)+ Purchase of common and pref. stock (115) + Cash dividends (127)

$C F_{D}=$ - Long-term debt issuance (111) + Long-term debt: reduction (114) - Changes in current debt (301) + Interest expense (15) 
Missing and combined data code entries are set to zero. We then check that the discrepancy between $C F_{O}-C F_{K}$ and $C F_{E}+C F_{D}$ is less than $\$ 10,000$ and use only observations where this is the case. Out of 239,750 observations, this eliminates only 10,895 observations (less than 5\%), and the number of eliminated observations does not appear to vary in a quantitatively important or systematic way by year. 
Table 1: Simulation: Parameterization

\begin{tabular}{|c|c|c|c|c|c|c|}
\hline \multicolumn{7}{|c|}{ Preferences } \\
\hline \multicolumn{7}{|c|}{$\beta$} \\
\hline \multicolumn{7}{|c|}{0.96} \\
\hline \multicolumn{7}{|c|}{ Technology } \\
\hline$\alpha$ & $\delta$ & $p$ & $q$ & $\sigma_{K}$ & $\sigma_{I}$ & $\rho_{L}$ \\
\hline 0.333 & 0.1 & 0.5 & 0.5 & 0.03 & 0.03 & 0.01 \\
\hline
\end{tabular}

Costs of External and Internal Finance

$\phi_{\mathcal{M}} \phi_{\mathcal{J}}$

$2 \quad 0.05$

Table 2: Simulation Results: Conditional Means, Prices and Expected Returns

\begin{tabular}{ll|rrr}
$A_{K}$ & $A_{I}$ & $\mu_{L}$ & $E\left[R_{L}\right]$ & $E\left[R_{K}\right]$ \\
\hline $\mathrm{H}$ & $\mathrm{H}$ & 1.008 & 1.008 & 1.069 \\
$\mathrm{H}$ & $\mathrm{L}$ & 1.000 & 1.015 & 1.017 \\
\hline $\mathrm{L}$ & $\mathrm{H}$ & 1.013 & 1.003 & 1.066 \\
$\mathrm{~L}$ & $\mathrm{~L}$ & 1.004 & 1.014 & 1.016
\end{tabular}


Table 3: Simulation Results: Conditional Means, Policy Function

\begin{tabular}{ll|rrrrrrrr}
$A_{K}$ & $A_{I}$ & $K^{\prime}$ & $L^{\prime}$ & $F$ & $D^{\prime}$ & $L^{\prime}-L$ & $Y$ & $I$ & $C$ \\
\hline $\mathrm{H}$ & $\mathrm{H}$ & 3.678 & 0 & 0.013 & 1.190 & -0.017 & 1.578 & 0.427 & 1.167 \\
$\mathrm{H}$ & $\mathrm{L}$ & 3.580 & 0.052 & -0.010 & 1.181 & 0.035 & 1.578 & 0.352 & 1.190 \\
\hline $\mathrm{L}$ & $\mathrm{H}$ & 3.595 & 0 & 0.024 & 1.177 & -0.017 & 1.486 & 0.346 & 1.156 \\
$\mathrm{~L}$ & $\mathrm{~L}$ & 3.540 & 0.014 & 0.002 & 1.173 & -0.003 & 1.486 & 0.311 & 1.178
\end{tabular}

Table 4: Simulation Results: Circulation of Funds

\begin{tabular}{ll|rrrr}
$A_{K}$ & $A_{I}$ & $C F_{O}$ & $C F_{K}$ & $C F_{E}$ & $C F_{D}$ \\
\hline $\mathrm{H}$ & $\mathrm{H}$ & 1.577 & 0.410 & -0.013 & 1.180 \\
$\mathrm{H}$ & $\mathrm{L}$ & 1.577 & 0.388 & 0.010 & 1.180 \\
\hline $\mathrm{L}$ & $\mathrm{H}$ & 1.486 & 0.329 & -0.023 & 1.180 \\
$\mathrm{~L}$ & $\mathrm{~L}$ & 1.486 & 0.308 & -0.002 & 1.180
\end{tabular}

Table 5: Regression Results: Model and Flow of Funds Data

For the model data, results are from a regression of the value of aggregate liquidity $\mu_{L}$ on the financing shortfall $-\left(C F_{O}-C F_{K}\right)$, and four lags. For the flow of funds data, results are from a regression of the CP-Bill spread (orthogonalized with respect to the Baa-Aaa credit spread and HP filtered) on $-\left(C F_{O}-C F_{K}\right)$ (normalized by the exponential of the HP filtered $\log C F_{O}$ series).

\begin{tabular}{l|rr|rr} 
& \multicolumn{3}{r}{ Model } & Data \\
\hline & coefficient & standard error & coefficient & standard error \\
\hline constant & 1.11 & 0.06 & 0.16 & 0.06 \\
$s f_{t}$ & 0.25 & 0.04 & 0.55 & 0.56 \\
$s f_{t-1}$ & -0.09 & 0.04 & 2.37 & 0.65 \\
$s f_{t-2}$ & -0.05 & 0.04 & -1.09 & 0.65 \\
$s f_{t-3}$ & -0.03 & 0.04 & -0.58 & 0.56 \\
\hline Adjusted $R^{2}$ & 0.48 & & 0.45 &
\end{tabular}


Figure 1: Circulation of Funds in a Modigliani Miller Economy

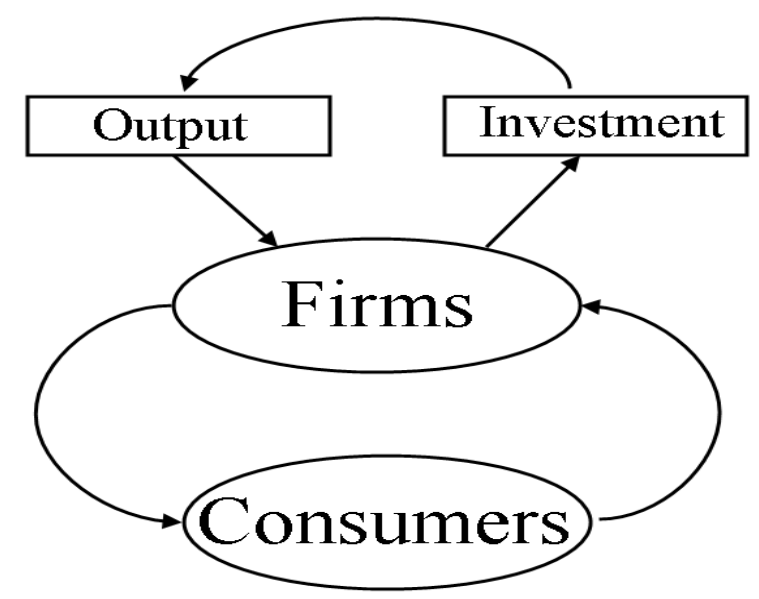

Figure 2: Circulation of Funds in an Economy with Myers and Jensen Costs

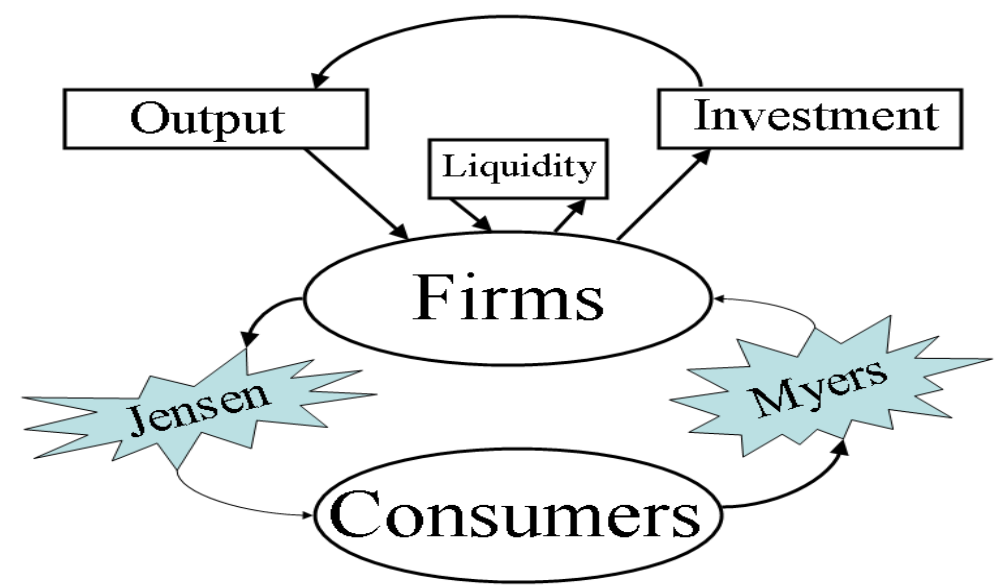


Figure 3: Conditional Expected Returns to Liquidity (solid) and Capital (dashed). Productivity is high in the top two graphs, and low in the bottom two graphs. Investment opportunities are high in two left hand side graphs, and low in the two right hand side graphs.
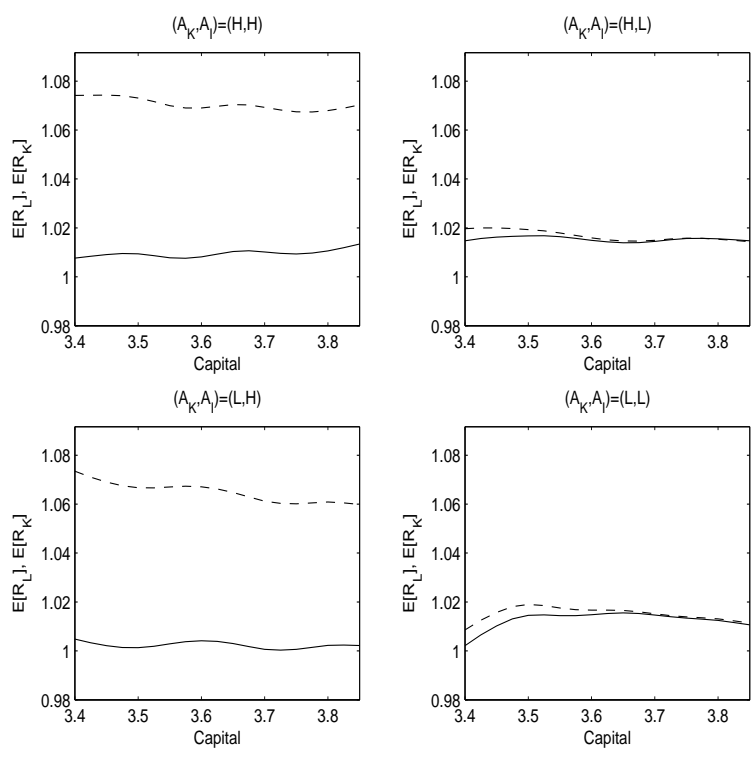

Figure 4: Policy Function for Liquidity Accumulation (solid) and Investment (dashed). Productivity is high in the top two graphs, and low in the bottom two graphs. Investment opportunities are high in two left hand side graphs, and low in the two right hand side graphs.
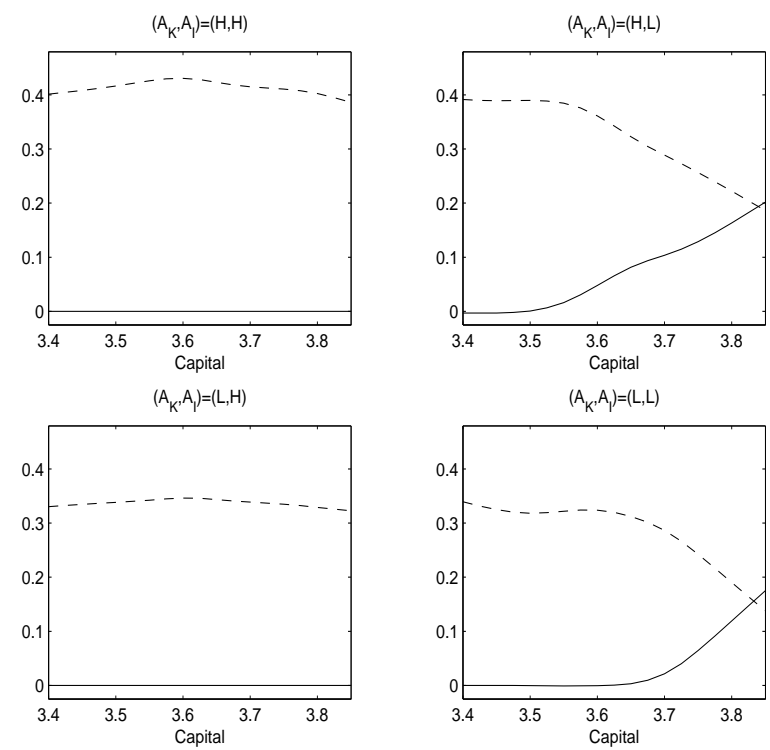
Figure 5: Policy Function for External Finance. Productivity is high in the top two graphs, and low in the bottom two graphs. Investment opportunities are high in two left hand side graphs, and low in the two right hand side graphs.
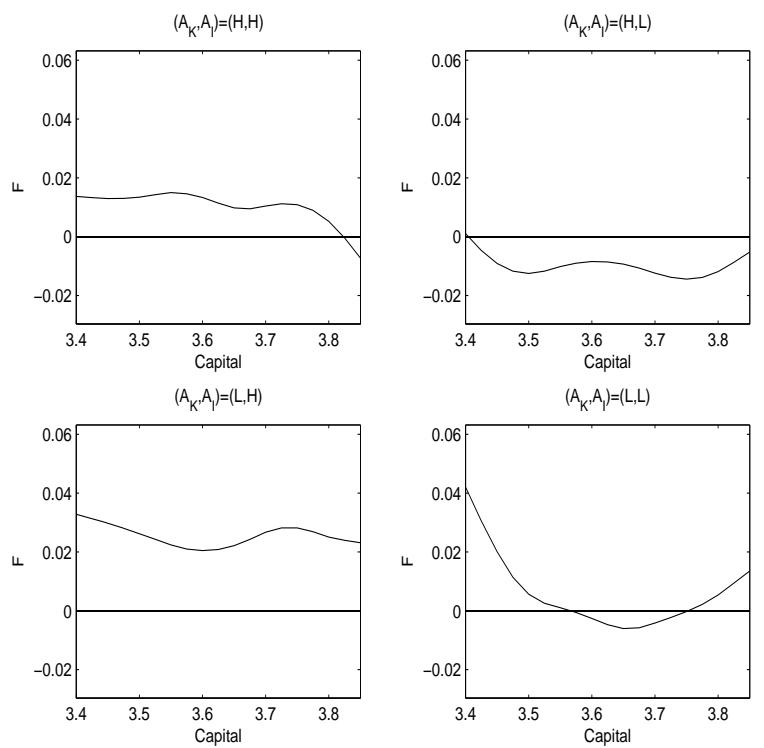

Figure 6: Policy Function for Payout Commitments. Productivity is high in the top two graphs, and low in the bottom two graphs. Investment opportunities are high in two left hand side graphs, and low in the two right hand side graphs.
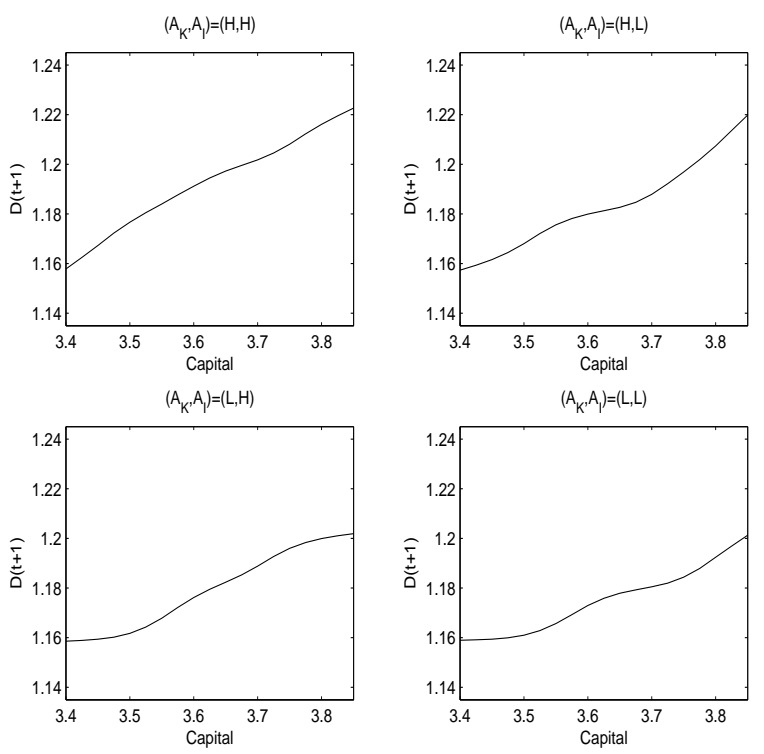
Figure 7: Simulation Results: Liquidity Premium, $\left(\frac{\mu_{L}}{\mu_{C}}\right)$; Financing Shortfall, - $\left(C F_{O}-C F_{K}\right)$; Discretionary Payouts (+) or External Finance (-), (F); Liquidity Accumulation, $\left(L^{\prime}-L\right)$.
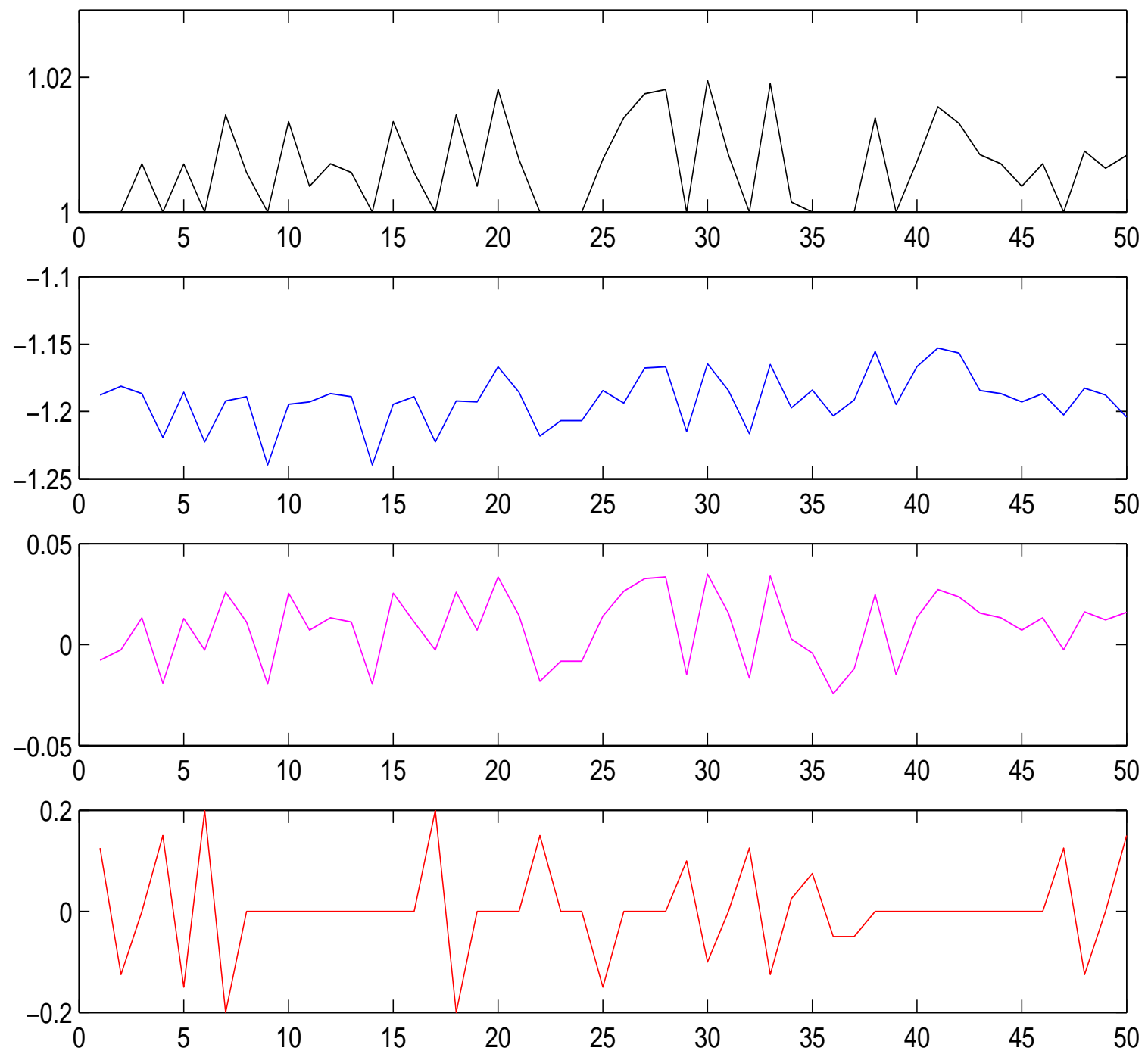
Figure 8: Circulation of Funds in Compustat Data

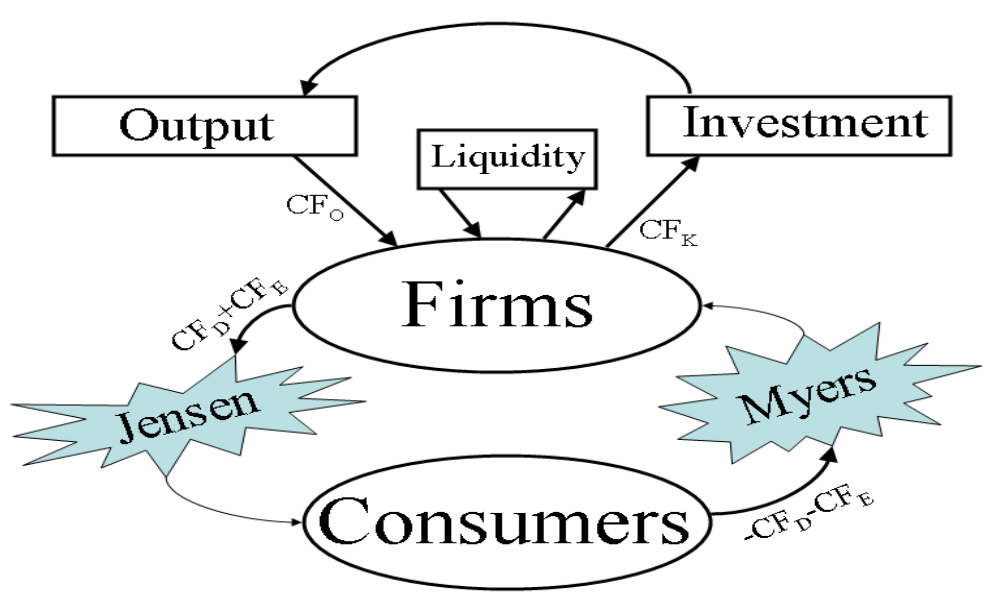


Figure 9: Aggregate Circulation of Funds (US Flow of Funds)

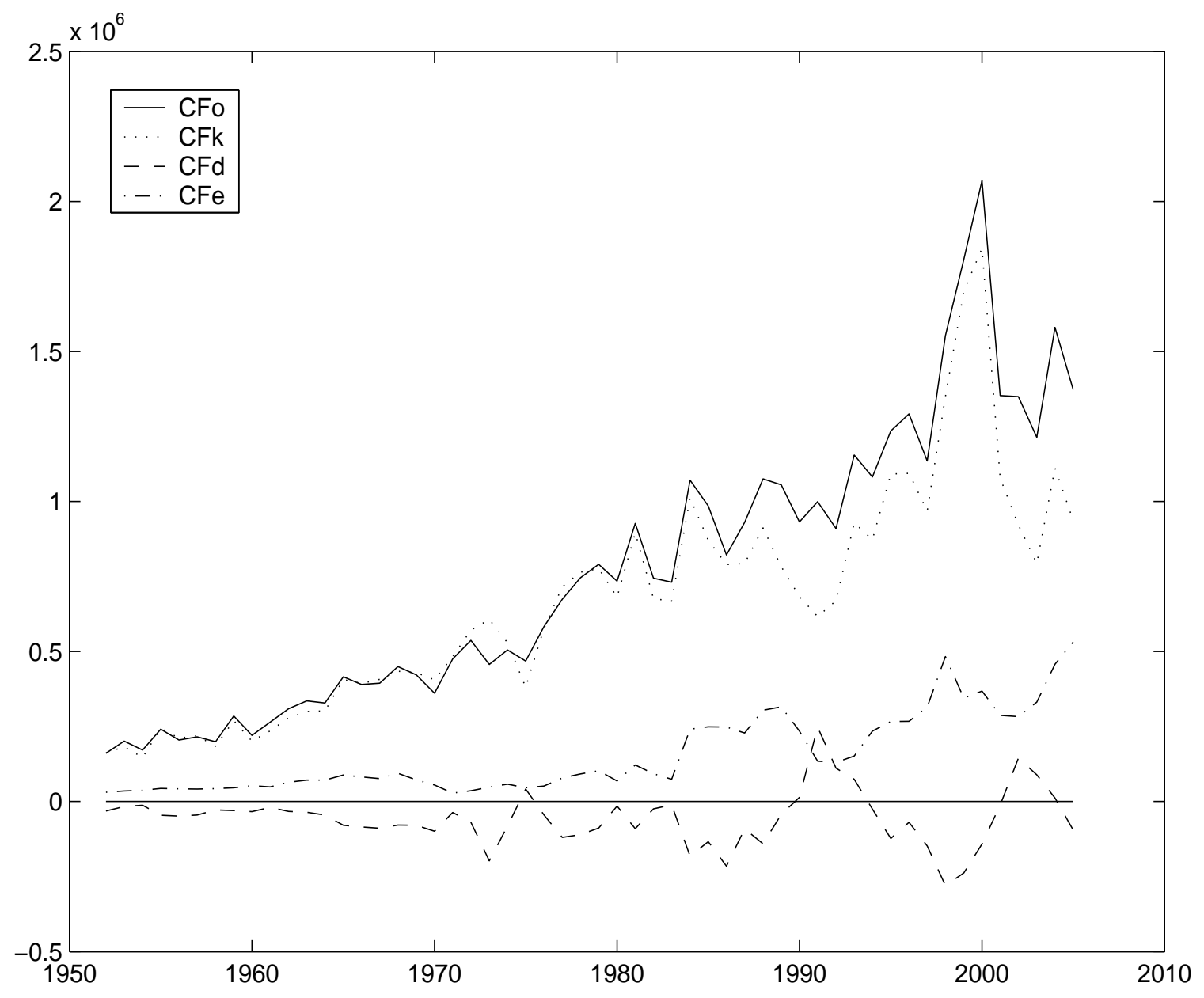


Figure 10: Aggregate Circulation of Funds as a Percent of Cash Flows from Operations $\left(C F_{O}=1\right)$ (US Flow of Funds). Bottom panel breaks out cash flow to capital into flows to physical capital $\left(C F_{K n l}\right.$, higher dashed line) and flows into liquid assets $\left(C F_{K l}\right.$, lower dotted line)
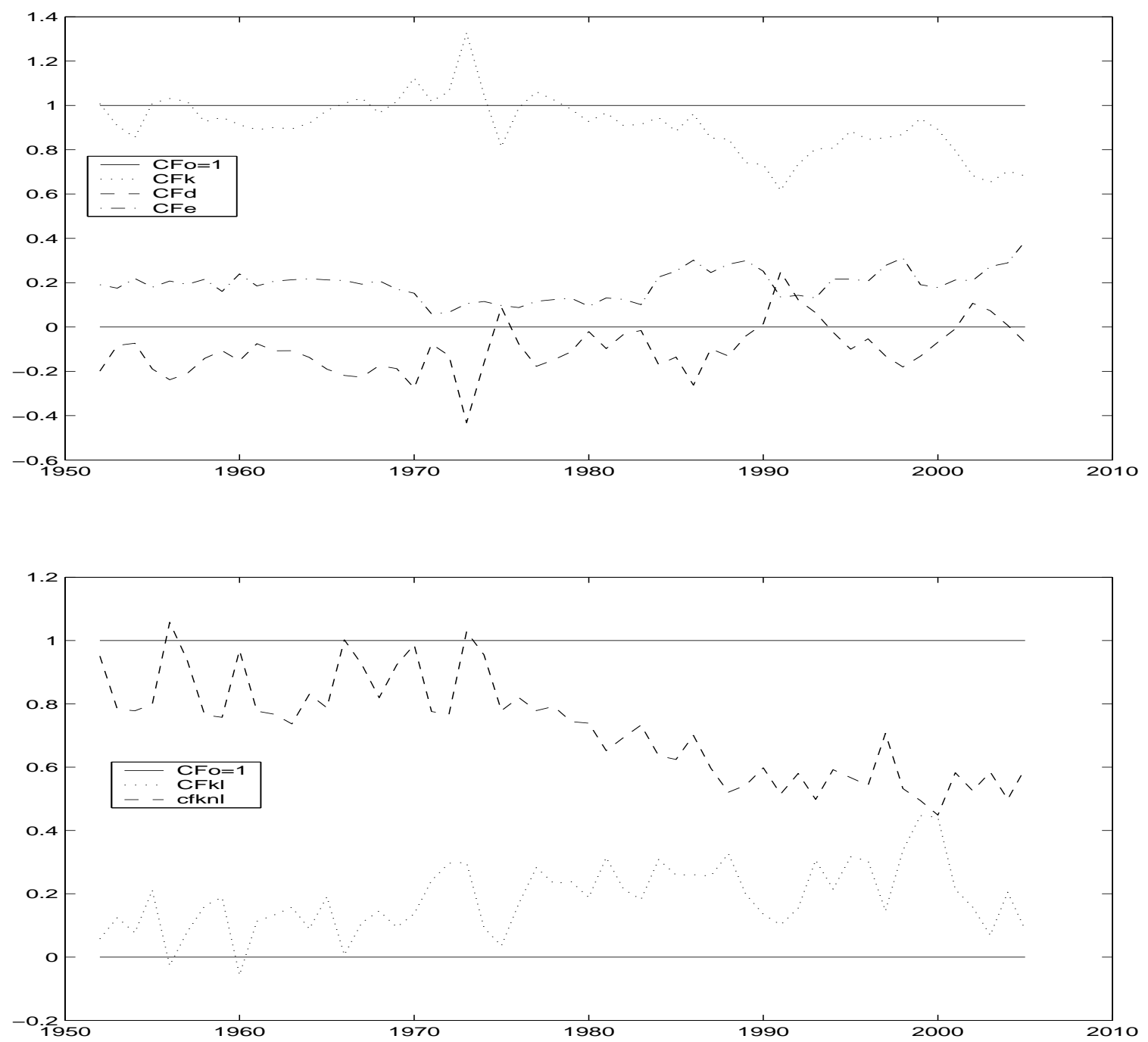
Figure 11: Shortfalls: Top panel plots aggregate shortfalls in Flow of Funds and Compustat. Bottom panel plots aggregate shortfalls and sum of firm level shortfalls in Compustat data.
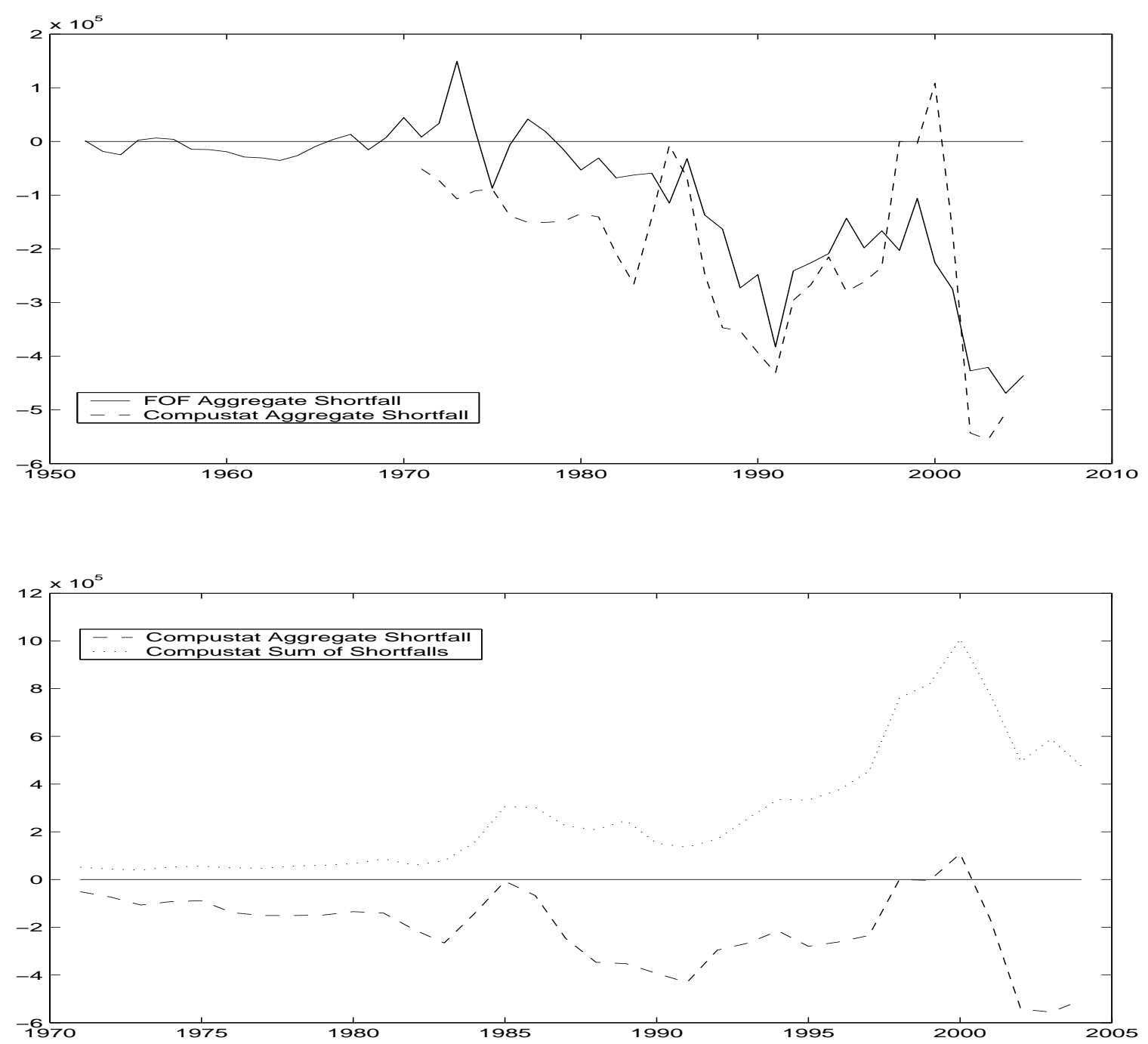
Figure 12: The contemporaneous and lead-lag correlation between Shortfalls and the Spread between 3 Month AA Nonfinancial Commercial Paper and Treasury Bills. The CP-Bill spread is the HP filtered error from a regression of the CP-Bill spread on the Baa-AAA spread and the shortfall series has been normalized by the exponential of the HP filtered $\log C F_{O}$ series.
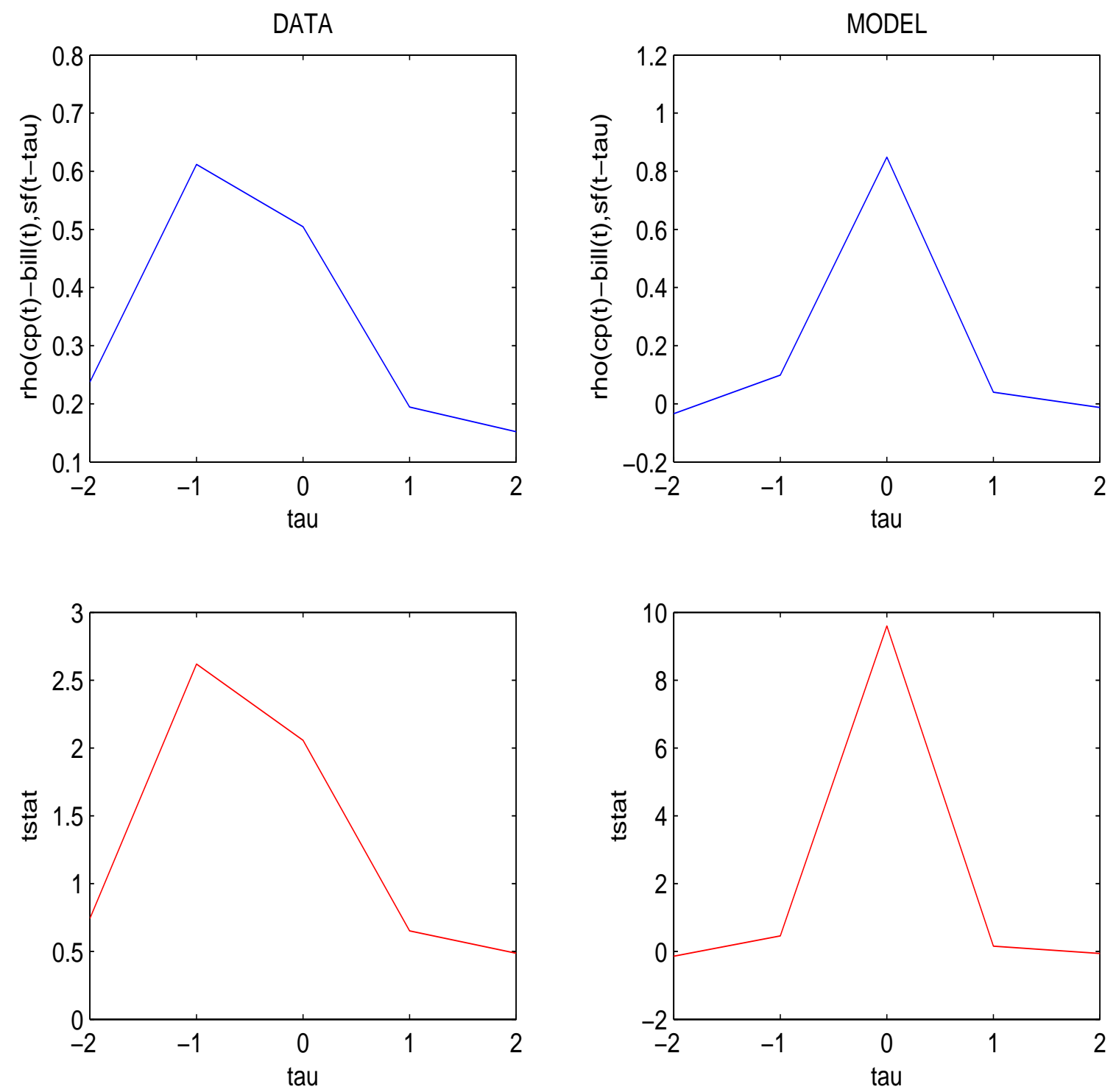